\title{
Decision Processes in Introducing Hybrid Agricultural Plants: ECOM Coffee Group Case Study
}

\author{
Bernard Kilian, Roy Zúñiga, and Jorge-Vinicio Murillo \\ INCAE Business School, Alajuela, Costa Rica
}

\author{
Bernard.Kilian@incae.edu Roy.Zuniga@incae.edu \\ Jorge.Murillo@incae.edu
}

\begin{abstract}
This paper presents the impacts of an innovative project in the coffee business, carried out in Nicaragua. ECOM, a major coffee exporter, had invested in a coffee renovation project with hybrid plants but faced the challenge of selling these plants to local coffee farmers. A student consulting team was assigned to the project, which helped ECOM to develop an innovative sales structure to increase profitability for both farmers and ECOM. This project opened new information pathways between ECOM coffee and academics. ECOM benefited from case research on this issue and from the ensuing discussion with students and faculty; the school benefits from having access to the company to document real experiences that provide learning experiences for students.
\end{abstract}

Keywords: Coffee industry, agribusiness chains, case method, informing systems, hybrid plants, Nicaragua.

\section{Introduction}

In early 2010 executives of an international coffee exporting firm approached the agribusiness faculty of a well-known Central American business school for assistance in a decision to continue investing in the research and production of hybrid plants. The faculty assigned a five-person team of students to analyze the agribusiness chain and make recommendations. Based on the student analysis, a case study (shown in the Appendix) was developed for classroom discussion. The case was subsequently discussed among the faculty, the student research team, and the case protagonists.

Material published as part of this publication, either on-line or in print, is copyrighted by the Informing Science Institute. Permission to make digital or paper copy of part or all of these works for personal or classroom use is granted without fee provided that the copies are not made or distributed for profit or commercial advantage AND that copies 1) bear this notice in full and 2) give the full citation on the first page. It is permissible to abstract these works so long as credit is given. To copy in all other cases or to republish or to post on a server or to redistribute to lists requires specific permission and payment of a fee. Contact Publisher@InformingScience.org to request redistribution permission.
This paper is organized as follows. The first section describes the research design, which was developed by the students in response to the situation faced by the case protagonists. The second section presents the results of the research, based upon an analysis of the data in the appended case study. The third section is a discussion of the informing outcomes. Section four offers conclusions. 


\section{The Research Design}

Given the low productivity of coffee growers in Mexico and Central America and the importance of this region to ECOM as a major coffee exporter in the region, company executives decided in 2003 to invest in a coffee renovation project using hybrid plants. The focus of the project, based in a research station in Nicaragua, was to achieve higher yields, greater economic benefits for producers, improved harmony with the environment, enhanced characteristics in the cup (tastes and aroma of brewed coffee), plants with a higher resistance to pests, and longer harvest periods through the use of hybrid plants.

In undertaking this project, ECOM executives were searching for a strategy that would generate profits for the company while increasing monetary incentives for participating producers. To this end, they approached members of the agribusiness faculty of a well-known Central American business school for assistance. The faculty assigned a five-person team of students to gather data, conduct an analysis of the alternatives, and prepare recommendations. This research was conducted under faculty supervision.

Based on their analysis of the data, two alternatives were identified. The first alternative, an increase in the current price of the hybrid coffee plants, resulted in an unfavorable outcome for producers, since the price at which the project would become profitable would leave producers with a negligible increase in profit margins; therefore, producers would have no incentive to opt for the renewal with hybrid coffee plants. As a second alternative, the student research team proposed that ECOM retain a percentage of the increase in production that the producers would obtain by renewing with hybrid plants. This alternative showed positive results for producers. The percentage retained, at which the project would become profitable, would leave the producers with a twenty percent increase in profit above that obtained by renewing with conventional plants. As a third alternative, ECOM could implement a mixed strategy that included increasing prices and defining a rate of retention.

An analysis of the impact on profits for different participants in the agribusiness chain of the project revealed that by selling its hybrid plants in the final phase of plant development rather than at intermediate phases, investments in fixed assets for the members of the agribusiness chain would be diminished. These members did not have to invest in nursery facilities, but ECOM did, making it more difficult for the ECOM Project to become profitable. Thus an analysis of a strategy to recover ECOM's investment was performed. Finding that ECOM could ask a higher percentage of retention of the increases in production, the result was that the producers would have 18.6 percentage points more than if they renewed with conventional plants. Producers would now have an incentive to buy the product.

To gather the information needed for this project, the student research group visited the laboratory in Nicaragua and the farm in charge of the production and distribution of the hybrid coffee plants. In the visit to the laboratory, the consulting group shared ideas, opinions and thoughts with Dr. Fred Georget, R\&D manager for CIRAD, the French agency collaborating with the project and with Eduardo Garcia, Production Manager, who provided the group with cost information allocated to each of the phases. Through these discussions, bottlenecks in the agribusiness chain were identified.

The student research group also examined the cost / benefit ratio that a hybrid plant would produce. To see how much more production per hectare the hybrid plants would yield, the group used data provided in Nicaragua through a client database that had already has been using hybrid coffee plants and through visits to plantations used as pilot projects.

Finally, the group met in the Nicaraguan city of Matagalpa with Reynaldo Soza, Regional Manager in charge of promoting and receiving feedback from producers who had implemented and 
planted the hybrid plants in their farms. He provided the group with different opinions and facts that had been shared with him by producers who had bought the hybrid plants.

Once the final results were presented and approved by managers of the company, the case study was developed by the supervising faculty members. The case describes the environmental context of the hybrid plant decision and presents information required for the evaluation of the costs and benefits of the different alternatives.

To develop this case study, it was necessary to conduct further interviews with project technical personnel and management. Information from these interviews was in addition to information presented in the student research report. All the information in the case was validated by company executives.

\section{Findings: The Informing Outcomes}

The section presents our findings with respect to the informing outcomes. These outcomes are portrayed in terms of (a) the experience of ECOM Coffee Group using the teaching case and its impact on practice, and (b) the sequel. This is followed by a conclusions section in which we explore the new informing pathways.

\section{Can Teaching Cases Have a Positive Impact on Practice? The Experience of ECOM Coffee Group}

The student consulting team completed its report in late 2009 and presented it to a faculty panel during the first week of 2010. The case protagonists were present including the decision-maker, Mr. Esteve, the project economist, Edgardo Alpizar, and a technician from the French research agency, CIRAD. It was the first time that the invitees had seen the final figures comparing the returns from a hectare planted in conventional coffee plants with one planted in hybrid plants. The potential for significantly improving the returns to even the smallest producers caused excited discussion among the participants. Why had these impressive results not been achieved by any of ECOM's suppliers? Or had they been achieved by some, without ECOM's knowledge?

The student presentation also included a diagnosis of the company organization. ECOM's business was selling coffee and it had a strong sales force for this purpose. The research center in Nicaragua had no sales force. It was staffed by a biotechnologist as project director and several technical personnel to manage operations. Given that the adoption of hybrid plants required financial investments and important changes in cultivation practices, it was quite possible that many of ECOM's suppliers, $85 \%$ of whom were small producers, were reluctant to shift to the new technology. The students suggested an organizational change that would add a specialized sales department, the cost of which would be offset by a reduction in the number of technicians in the operating department. The students also recommended that a department for credit analysis be added, to open access to sources of financing.

\section{Discussion}

In the discussions that followed the presentation, other ideas were suggested to deal with the project's operating losses. Aggressive sales and marketing efforts might be accompanied by an expansion of the facilities to permit increasing sales volumes and revenues. The larger producers, who were benefitting substantially from increases productivity, might be given the opportunity to invest in the project.

These discussions revealed diverse informing flows among the participants that are shown in Table 1. 
Table 1: Informing flows within and between researchers, students and practice

\begin{tabular}{|c|c|c|c|}
\hline & \multicolumn{3}{|l|}{ To: } \\
\hline From: & Faculty & Students & Practice \\
\hline Faculty & $\begin{array}{l}\text { Agribusiness cases are very } \\
\text { important in understanding } \\
\text { the limitations for rural } \\
\text { development. Therefore, } \\
\text { cases of this area are highly } \\
\text { relevant in understanding } \\
\text { causes of poverty and so- } \\
\text { cial development in rural } \\
\text { areas of Latin America. } \\
\text { Furthermore, agribusiness } \\
\text { cases have important links } \\
\text { to other academic areas } \\
\text { such as micro finance, sup- } \\
\text { ply chain management, and } \\
\text { the role of women. }\end{array}$ & $\begin{array}{l}\text { A key learning goal is that } \\
\text { students understand the } \\
\text { importance of productiv- } \\
\text { ity for farmers' income } \\
\text { and the financial limita- } \\
\text { tions that many small } \\
\text { farmers face in attempting } \\
\text { to improve productivity. }\end{array}$ & $\begin{array}{l}\text { In discussions with farmers, it was } \\
\text { found that productivity, and not } \\
\text { price, is not the most important fac- } \\
\text { tor in determining farm income. } \\
\text { Therefore, recognizing that it is } \\
\text { important to improve farm produc- } \\
\text { tivity is a central element of discus- } \\
\text { sion between faculty and farmers. }\end{array}$ \\
\hline Student & $\begin{array}{l}\text { Discussion among faculty } \\
\text { and students in this case } \\
\text { helped to improve the line } \\
\text { of argumentation of the } \\
\text { case. In some parts of the } \\
\text { case, information has been } \\
\text { added to complete the } \\
\text { analysis. }\end{array}$ & $\begin{array}{l}\text { Discussion among stu- } \\
\text { dents is very important to } \\
\text { gain an in-depth under- } \\
\text { standing of the case and } \\
\text { the context of rural farm- } \\
\text { ing. This is aided by stu- } \\
\text { dents in the class who } \\
\text { have grown up on the } \\
\text { farm or worked in agri- } \\
\text { business. }\end{array}$ & $\begin{array}{l}\text { Innovative, out-of-the-box ideas } \\
\text { from students with no relation to } \\
\text { agribusiness help practitioners to } \\
\text { see the situation in a new light. }\end{array}$ \\
\hline Practice & $\begin{array}{l}\text { An important insight for } \\
\text { faculty from discussion } \\
\text { with practitioners is to un- } \\
\text { derstand the practical, real- } \\
\text { world limitations to im- } \\
\text { proving productivity. These } \\
\text { limitations result in many } \\
\text { cases from limited access } \\
\text { to resources and informa- } \\
\text { tion. }\end{array}$ & $\begin{array}{l}\text { Interaction between stu- } \\
\text { dents and practitioners } \\
\text { significantly improves the } \\
\text { students' understanding of } \\
\text { the situation faced by } \\
\text { practitioners. }\end{array}$ & $\begin{array}{l}\text { Sharing of information among pro- } \\
\text { ducers facilitates learning from each } \\
\text { other and to translate the findings of } \\
\text { the faculty into the real life situation } \\
\text { of the practitioners. Very often pro- } \\
\text { ducers are able to provide examples } \\
\text { which are closer to their concrete } \\
\text { situation in the field. Finally, some } \\
\text { practitioners are able to report first- } \\
\text { hand experience with the new varie- } \\
\text { ties which increases the willingness } \\
\text { of others to test them. }\end{array}$ \\
\hline
\end{tabular}

Later in 2010, the ECOM Coffee Group created a new Department of Technology Transfer, and Mr. Alpizar, who had been an active participant in the discussions following the student presentation, was named as its manager. The company also strengthened its Department of Sustainability, responsible for certifications and environmentally friendly practices. By 2013 these initiatives had begun to produce results. Sales of hybrid plants had increased by 131\% from 2009 to 2012, and operating losses were reduced significantly. Prospects for 2013 were even brighter. A greater percentage of coffee exports were of the sustainable variety, yielding prices between US $\$ 2$ to $\$ 10$ above those received for conventional varieties. Sustainable coffee sold by ECOM increased from $11 \%$ of its total sales in 2008 to $14 \%$ in 2011. 
"There is now more space for innovation by members of the management team," commented Mr. Alpízar. "It's not just about producing hybrid plants more profitably. It's also about finding ways for the coffee grower to produce more and how to sell this differentiated product more profitably in the marketplace."

The company also created a diversification department, which oversaw both product line and service diversification. An example of the company's diversification was its decision to begin producing Robusta coffee and cacao in Nicaragua. At the same time, ECOM began to use indicators to monitor progress toward meeting its objectives.

According to Mr. Alpizar, the ECOM case was the first opportunity the company's management team had to look for innovative actions that would increase both the project's and the company's profitability. More than a hybrid plant business, this had been a process of continuous innovation that required creative and visionary personnel who saw the larger picture. "It's not just about producing the seedlings profitably..." said Mr. Alpizar, "It's also about finding the way to get producers to grow coffee, take the product to the market and sell it at a differentiated price..."

Currently, ECOM is working on an ambitious project to develop the company's own sustainability standard. According to Mr. Alpizar, the market has become saturated with other certifications that no longer differentiate one company from the next because so many producers have them. In addition, not all companies offer traceability of certified products. That is why ECOM has taken steps to ensure that its clients have greater value, while differentiating their certification from others that already exist in the market.

The part of the business that has been most fundamental to the company's sustainability platform began with the hybrid plant project. It was a project that they had to analyze and to improve in order to make it profitable; that allowed them to implement innovations that made the project more competitive. Differentiating the business provided the company with new opportunities in a market in which company margins from the sale of coffee had decreased in recent years. "We took a bet on something unique, and that's allowed us to have a competitive advantage against our traditional competitors..." concluded Mr. Alpizar.

\section{Conclusions: New Informing Pathways}

The student project opened new informing pathways between ECOM Coffee and the school. ECOM management noted that the analytic process during and after the student presentation was unlike their previous project evaluations, which they attributed to the involvement of senior academics in the process. This occurred at a critical time for ECOM, when the company had accumulated significant operating losses and was facing a new investment decision.

Three years after the research had been completed, the case served as documentation of the company's decision process at this critical juncture in its history. This has served not only as a learning vehicle for MBA students, but also in providing a basis for discussion and as a valuable instrument for the induction of new members of the ECOM management team, allowing them to understand a real situation that the company faced at one point in its history.

The relationship between the business school and the ECOM Coffee Group has continued over the years and has provided new opportunities for the documentation and discussion of new situations. In 2013 the company was interested in analyzing the ways in which coffee exporters might organize themselves to receive shared services, while remaining as competitors in the market. The company would benefit from case research on this issue and from the ensuing discussion with students and faculty the school benefits from having access to the company to document real experiences that provide learning experiences for students. 
Facilitating this case discussion has led to insights for the faculty. The analysis has shown that there is a need to incorporate more technology and innovation. This conclusion is consistent with the alternative suggested in the ECOM case as a possible solution to the problem facing the producers supplying the coffee company.

\section{Biographies}

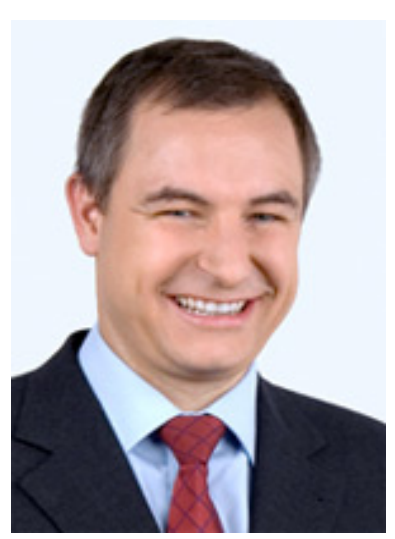

Bernard Kilian was born in 1969 in Germany. He finished his master's degree in "Agricultural Science" with emphasis on applied economics at the University of Hohenheim, Stuttgart. He holds a PhD in resource economics from the Department of Farm Management. From 2000 to 2002 Mr. Kilian was in charge of the Economic subproject of a national interdisciplinary research project in Precision Agriculture. Since spring $2003 \mathrm{Mr}$ Kilian is part of the team of CIMS-Foundation, with domicile at INCAE, Costa Rica, where he occupies the position of CIMS Director of Research. Mr. Kilian received the Emerald Award of excellence for publishing one of the best papers in management in 2006. In 2010 Mr. Kilian was promoted to associate professor at INCAE Business School.

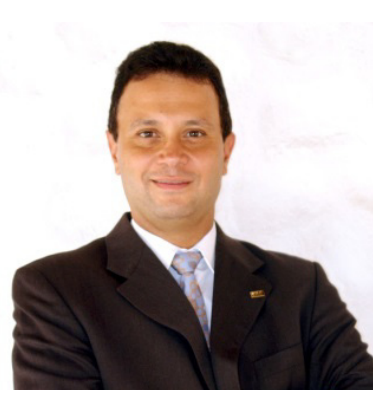

Roy Zúñiga, Costa Rican. Ph.D. Eng. from the Universidad de Valladolid, Spain (Agencia Española de Cooperación Internacional Scholarship Award). M.Phil. from Manchester School of Management (British Chevening Scholarship Award), M. Sc. in Interdisciplinary Studies from the University of Oregon, USA (Fulbright Scholarship). MBA degree from INCAE Business School (Incae Scholarship). He has consulted with the World Bank, served as Advisor to the Costa Rican Industrial Reconversion Program, Executive Director for INCAE, General Manager and Production Manager for private companies. He is a full professor and was Dean of INCAE Business School, in charge of: Executive Education, Latin American Center for Competitiveness and Sustainability, Faculty, Costa Rican Campus, and the areas of Human Resources, Technology and Operations.

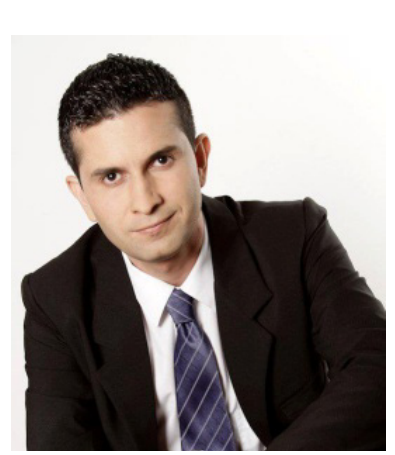

Jorge-Vinicio Murillo is Project Manager and Senior Researcher of the Center for Competitiveness and Sustainable Development (CLACDS) at INCAE Business School. His research includes studies on effectiveness of programs to fight against poverty, association of small and medium enterprises, citizen security in Central America, competitiveness of agro-industrial clusters in Latin America and corporate social responsibility, among others. Jorge-Vinicio received a Bachelor of Food Engineering at the University of Costa Rica. He later did a Master's in Business Administration and a concentration in Sustainable Development at INCAE Business School and then received training in the area of Business Research at The Real Colegio Complutense in Harvard University. Jorge-Vinicio has been a member of the Faculty of EARTH University in Costa Rica since 2003, where he teaches courses in Strategic Management 


\section{Appendix: The Case}

In February 2010 Mr. Edward Esteve, CEO of the ECOM Coffee Group, was faced with the decision of whether to invest over a half million dollars during the next two years for the production and sale of hybrid coffee plants to the company's suppliers in Mexico and Central America. A team of MBA students from a well-known Central American Business school, working under the supervision of the agribusiness faculty had presented an analysis of the financial feasibility of the investment. Mr. Esteve was now reviewing the results of that study.

\section{The Company}

The ECOM Coffee Group was a division of ECOM Agro-Industrial Corporation, founded in Barcelona, Spain, in 1840 and currently a major global processor and seller of cotton, coffee, oilseeds, and cocoa. The Coffee Group specialized in the purchase, milling, storage, and distribution of fresh coffee beans from producing countries, mostly on the American continent, to consumers around the world. Over $25 \%$ of all coffee sold worldwide by ECOM was purchased from producers in Mexico and Central America. The company competed on price with other global coffee exporters, selling conventional varieties of "Arabica" and "Robusta" beans to roasters of branded products such as Nestlé or to large restaurant or retail chains such as McDonald's or Wal-Mart.

In recent years, world demand for coffee had remained strong but producers' margins had declined. ECOM's suppliers were therefore reluctant to invest in the renovation of their plantings, and their productivity had suffered as a result. Faced with declining supplies in its major producing countries, ECOM faced the prospect of losing customers to the competition. The company was responding by seeking ways to help its growers increase their productivity, and by encouraging them to shift from conventional to "sustainable" practices which included the use of organic varieties and socially responsible labor policies. Growers who followed these practices were able to obtain certifications that enabled them to sell at higher margins. Major certifications for coffee included Orgánico, Fairtrade, Rainforest Alliance, Bird Friendly, UTZ Certified, and Starbucks C.A.F.E. Practices. The Fairtrade certification is a guarantee of both environmental and social sustainability, and Fairtrade products demand a premium price. Currently, 12 percent of ECOM Coffee's exports were classified as sustainable, and Mr. Esteve had plans to increase the company's exports of sustainable coffee to $30 \%$.

ECOM's new sustainable coffee strategy rested on four pillars: (1) providing its buyers with differentiated products by forming alliances to improve quality at all stages of the agribusiness chain; (2) demanding that its suppliers achieve greater productivity, quality, and profitability by providing them with know-how and credit; (3) ensuring that ECOM continue to be a reliable, low-risk client for its banking partners; and (4) forging a broad, long-term vision that includes sustainable production and the preservation of the environment. "These four points will allow ECOM to promote sustainability along the entire supply chain, which is in line with our goal to market a more sustainable coffee," said Mr. Esteve.

\section{The World Coffee Industry}

Coffee was among the world's most widely traded commodities (data on world production and consumption are presented in Exhibit 1). Global demand remained high, and many experts thought that it would remain at current levels despite the world economic recession. Though they expected that fewer people would visit coffee houses, they believed that consumers would continue to drink coffee at home. Per capita coffee consumption was declining in Europe, but growing in coffee exporting countries and emerging economies. 
Coffee production was a major source of income for many developing countries. It was estimated that some 20 million families around the world worked directly in coffee production, and many others depended on jobs in processing and commercialization. Between 2001 and 2009 the portion of coffee produced for export in Mexico and the Central American countries declined (see Exhibit 2) as a result of lower productivity, mainly because the producers, earning lower margins, were not investing in the replacement of their plantations, many of which were reaching the end of their useful life (the optimal period for coffee plantings was estimated in 20 years). Many producers, including ECOM's suppliers, were turning to alternative crops. According to a study by CIMS (Kilian et al., 2013), the major challenge facing the industry in Central America was to reverse the long-term trend in declining productivity with its negative effect on family incomes.

Freshly-picked coffee was processed by wet-milling. Coffee mills de-pulped, washed, peeled and sorted the coffee. They also dried, stored and sold the product for the coffee farmers. During the milling process, the coffee fruit that was delivered to the mill when mature (coffee cherries) was processed to beans for export. Exporters bought coffee beans from the mills and sold them in the international market. There were different types of mills; some belonged to cooperatives of producers, while others were owned by the same export company.

The international commercialization of coffee was performed by a few large export houses, which in Central America included ECOM Coffee Group, Mercon Coffee Corporation, Volcafé, and Neumann Kaffee Gruppe. These exporters competed for high quality and consistent suppliers. They were also vertically integrated in processing and had their own mills to depulp the coffee. In addition, they dried the beans and stored them at their own facilities. Exhibit 3 illustrates the coffee production process.

The Figure 1 shows the price per pound of coffee at each of the major stages of the value chain.

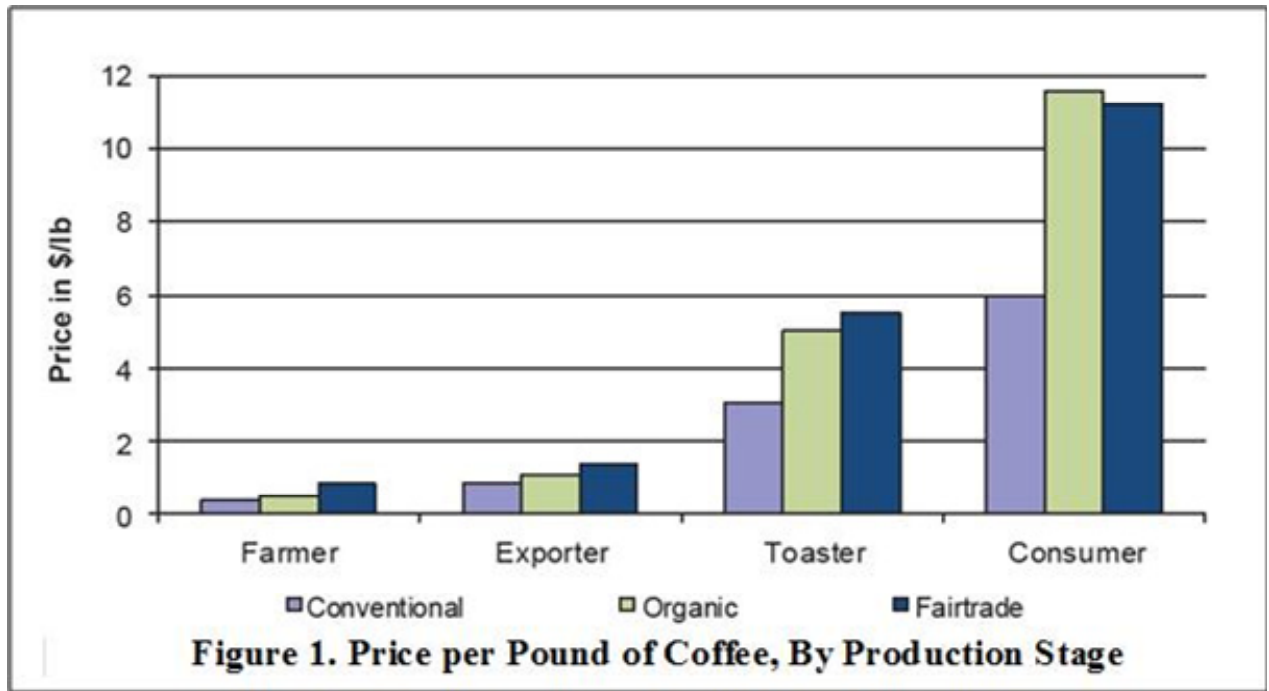

Source: Based on CIMS \& Giovannucci, 2010

They sold the processed beans to coffee roasters in the major consuming countries of North America and Europe at prices that were influenced by the international commodity markets, with premiums for quality. The coffee roasting process included cleaning, roasting, grinding and packaging. This process changed the physical and chemical properties of green coffee to produce organoleptic properties (i.e., taste, smell, etc.) in high roast coffee.

Coffee roasting was concentrated among a few companies in the international market with enormous purchasing power. Some ten roasters controlled $60 \%$ of the market; among them were Nestlé, Kraft Foods, Sara Lee and Procter \& Gamble. 
The growing popularity of sustainable coffee (see Exhibit 4) opened opportunities for higher margins, while changing the structure of the coffee industry with a proliferation of boutique roasters and gourmet brands. However, large integrated firms increasingly dominated the market for sustainable coffee: Nestlé's Nespresso which bought 780 thousand tons in 2009, Sara Lee which bought 450 thousand tons and Starbucks with purchases of 175 thousand tons. Coffee exporters still had to compete on the basis of volume to ensure reliable delivery, consistent quality, and competitive prices, which required large amounts of capital. For producers, a shift to sustainable coffee meant incurring the costs of certification, which was increasingly demanded by international retail chains such as Safeway, Kroger, Aldi and Sainsbury's.

\section{The Hybrid Coffee Project}

In 2003 ECOM invested in a project for the renovation of coffee plantings in Nicaragua using hybrid plants. To implement the project, ECOM formed a 15-year alliance with CIRAD, a French public research firm that was working in developing countries to "generate and transfer new knowledge, support the development of agriculture and strengthen debate on major agricultural issues."

CIRAD was producing hybrid coffee plants using a technique known as embryogenesis somática, which resulted in the plants' multiplying on a commercial scale. This process began with the production of embryos from a sample of plant leaves collected in the field, and the rapid propagation of plants identical to the "mother plant." The total process consisted of five phases (see Exhibit 5)

The hybrid plants were reported to have several advantages: 40 percent higher productivity, fewer plants required per hectare (4,000 versus 5,800 for conventional plants), reduced environmental impact, greater resistance to disease, more rapid maturation (two years from planting to first picking versus three years for conventional plants), and improved flavor and aroma. These plants were also better adapted to dry climates and produced greater yields at lower altitudes, where the temperatures were higher. These advantages varied from one country and region to another, depending on the different costs of farm inputs, conventional coffee plants, labor, and inflation. The improvement in yields and the density of plantings per hectare depended on the cultivation skills and practices of the producers.

The project was based in low-lying Sébaco, Nicaragua, where the dry season extended to half the year. Alongside the CIRAD laboratory in Sébaco, ECOM had established an incubating facility for the seedlings in association with one of the major coffee producers of Nicaragua. They also established nurseries in the nearby mountain region of Matagalpa, where phases 2 through 4 of the process would take place. The project was staffed by a biotechnologist as project director and several technical personnel to manage operations. There was no one responsible for selling the hybrid plants.

As with any new technology that required years of research and development, the renovation of coffee plantations required an investment by the producers, many of whom had little or no access to credit. The project had no sales or technology transfer department, and Mr. Esteve realized that he would have to persuade both the producers and the financial institutions of the viability of these investments if the hybrid coffee technology was to be adopted on a broad basis by ECOM's suppliers.

From 2004 through 2009, the results of the project for ECOM Coffee had been as shown in Exhibit 6. The investments (see details in Exhibit 7) were of two types, based on their origin: tangible fixed assets; and operating expenses incurred since the beginning of the project to date, in order to achieve stable production. These expenses included high fixed costs, such as energy, salaries, travel, and technology transfer expenses for CIRAD experts. Mr. Esteve was aware that the 
company had to recover both the investments and the losses from operations that had been incurred over the past six years. Moreover, the corporate offices in Barcelona expected a $15 \%$ return on company projects.

\section{The Student Analysis}

The student team identified the variable costs for each hybrid coffee plant (see Exhibit 8), which included inputs, fertilizers, water and salaries for laboratory personnel and staff in other production areas.

Fixed costs (see Exhibit 9), which included maintenance of the installations and equipment, public utilities such as electricity and water, salaries of administrative personnel, and other office costs, assuming full capacity and mortality rates of $65 \%$ in Phase $1,85 \%$ in Phase 2 and $95 \%$ in Phases 3 and 4, were estimated by the student team.

The student team then projected the revenues expected from the sale of hybrid plants to coffee producers in each of the phases of production (see Exhibit 10). Due to the mortality rates in each phase, the number of embryos produced was greater than the sum of the plants sold in each phase. Moreover, since the projections exceeded the existing capacity of the ECOM facilities, the student consultants recommended expanding capacity, which required investments of US\$294,375 in the current year and US\$326,345 in 2011. They further recommended that the prices of the plants be maintained as follows: phase 0 , US\$ 0.30; phase 1, US\$ 0.41; phase 2, US\$ 0.52; and phases 3 and 4, US\$ 0.58 .

Finally, the student team calculated the returns that could be obtained by producers from one hectare of hybrid plants versus one hectare of conventional plants, using data from the Matagalpa area of Nicaragua, where $50 \%$ of the coffee was grown (see Exhibit 11).

\section{The Decision}

While Mr. Esteve understood the many advantages of hybrid plants for coffee producers and for ECOM as an exporter of quality coffee, he was also aware that $85 \%$ of the producers in Nicaragua and other Central American countries were small farmers on the border of subsistence, who were averse to risk and unable to obtain credit. Until now, it had not been possible to sell a sufficient number of hybrid plants to cover operating expenses and much less to earn a return on the investments that had been made over the years. He asked himself whether it was wise to invest another half million dollars in this project, now beginning its seventh year.

\section{References}

Kilian, B., Pratt, L., Hoadley, E., Rivera, L., Guevara, A., \& Lort-Phillips, L. (2012). Shared value in the coffee supply chain - An economic assessment of Nespresso's AAAprogram. Paper presented at the annual meeting of the BALAS Annual Conference, Adolfo Ibáñez University (UAI) School of Business, Rio de Janeiro, Brazil. 


\section{Exhibit 1}

World Production and Consumption of Coffee (thousands of bags $60 \mathrm{~kg}$ )

\begin{tabular}{|l|r|r|r|r|r|}
\hline \multicolumn{1}{|c|}{ Year } & \multicolumn{1}{c|}{$\mathbf{2 0 0 5}$} & \multicolumn{1}{c|}{$\mathbf{2 0 0 6}$} & \multicolumn{1}{c|}{$\mathbf{2 0 0 7}$} & \multicolumn{1}{c|}{$\mathbf{2 0 0 8}$} & \multicolumn{1}{c|}{$\mathbf{2 0 0 9}$} \\
\hline $\begin{array}{l}\text { TOTAL } \\
\text { PRODUCTION }\end{array}$ & $\mathbf{1 1 0 , 4 1 7}$ & $\mathbf{1 2 8 , 3 8 0}$ & $\mathbf{1 1 8 , 3 2 7}$ & $\mathbf{1 2 8 , 0 7 3}$ & $\mathbf{1 2 3 , 0 9 5}$ \\
\hline Africa & 13,026 & 15,385 & 14,810 & 15,493 & 15,835 \\
\hline Asia and Oceania & 30,215 & 34,530 & 31,410 & 35,055 & 36,861 \\
\hline $\begin{array}{l}\text { Mexico and Central } \\
\text { America }\end{array}$ & 17,118 & 16,937 & 18,294 & 17,305 & 16,855 \\
\hline South America & 50,058 & 61,529 & 53,813 & 60,220 & 53,544 \\
\hline
\end{tabular}

\begin{tabular}{|l|r|r|r|r|r|}
\hline \multicolumn{1}{|c|}{ Year } & \multicolumn{1}{c|}{$\mathbf{2 0 0 5}$} & \multicolumn{1}{c|}{$\mathbf{2 0 0 6}$} & \multicolumn{1}{c|}{$\mathbf{2 0 0 7}$} & \multicolumn{1}{c|}{$\mathbf{2 0 0 8}$} & \multicolumn{1}{c|}{$\mathbf{2 0 0 9}$} \\
\hline TOTAL CONSUMPTION & $\mathbf{1 1 9 , 0 0 5}$ & $\mathbf{1 2 2 , 5 7 9}$ & $\mathbf{1 2 7 , 2 0 3}$ & $\mathbf{1 3 0 , 0 0 4}$ & $\mathbf{1 3 1 , 2 8 9}$ \\
\hline Producing countries & $\mathbf{3 0 , 9 1 5}$ & $\mathbf{3 2 , 5 2 5}$ & $\mathbf{3 4 , 5 9 3}$ & $\mathbf{3 5 , 8 5 5}$ & $\mathbf{3 9 , 7 9 6}$ \\
\hline Importing countries & $\mathbf{8 8 , 0 9 0}$ & $\mathbf{9 0 , 0 5 4}$ & $\mathbf{9 2 , 6 1 0}$ & $\mathbf{9 4 , 1 4 9}$ & $\mathbf{9 2 , 4 2 9}$ \\
\hline European Union & 40,524 & 42,609 & 41,775 & 40,722 & 39,652 \\
\hline United States & 20,998 & 20,667 & 21,033 & 21,652 & 21,436 \\
\hline Japan & 7,128 & 7,268 & 7,282 & 7,065 & 7,130 \\
\hline Other importing countries & & & & & \\
& 19,440 & 19,510 & 22,519 & 24,710 & 21,584 \\
\hline
\end{tabular}

Source: International Coffee Org. Coffee Market Report 10/2009 and 4/2012 
Exhibit 2

\section{Coffee production for export from Mexico and Central America} (thousands of bags $60 \mathrm{~kg}$ )

\begin{tabular}{|l|r|r|r|r|r|r|r|r|r|}
\hline Country & $\mathbf{2 0 0 0 / 0 1}$ & $\mathbf{2 0 0 1 / 0 2}$ & $\mathbf{2 0 0 2 / 0 3}$ & $\mathbf{2 0 0 3 / 0 4}$ & $\mathbf{2 0 0 4} / \mathbf{0 5}$ & $\mathbf{2 0 0 5 / 0 6}$ & $\mathbf{2 0 0 6 / 0 7}$ & $\mathbf{2 0 0 7 / 0 8}$ & $\mathbf{2 0 0 8 / 0 9}$ \\
\hline Costa Rica & 2,044 & 1,872 & 1,668 & 1,511 & 1,521 & 1,420 & 1,256 & 1,517 & 1,353 \\
\hline El Salvador & 1,607 & 1,533 & 1,285 & 1,324 & 1,265 & 1,299 & 1,149 & 1,391 & 1,170 \\
\hline Guatemala & 4,690 & 3,369 & 3,770 & 3,310 & 3,403 & 3,376 & 3,650 & 3,800 & 3,070 \\
\hline Honduras & 2,437 & 2,836 & 2,296 & 2,768 & 2,345 & 2,974 & 3,231 & 3,382 & 2,913 \\
\hline Mexico & 3,510 & 2,938 & 2,851 & 2,701 & 2,367 & 2,500 & 2,200 & 1,950 & 2,450 \\
\hline Nicaragua & 1,419 & 934 & 1,015 & 1,357 & 940 & 1,528 & 1,110 & 1,510 & 1,410 \\
\hline Panama & 103 & 93 & 73 & 105 & 23 & 109 & 106 & 106 & 93 \\
\hline
\end{tabular}

Source: International Coffee Org. Coffee Market Report 10/2009 and 4/2012

\section{Exhibit 3}

The Agribusiness Chain for Coffee in Mexico and Central America

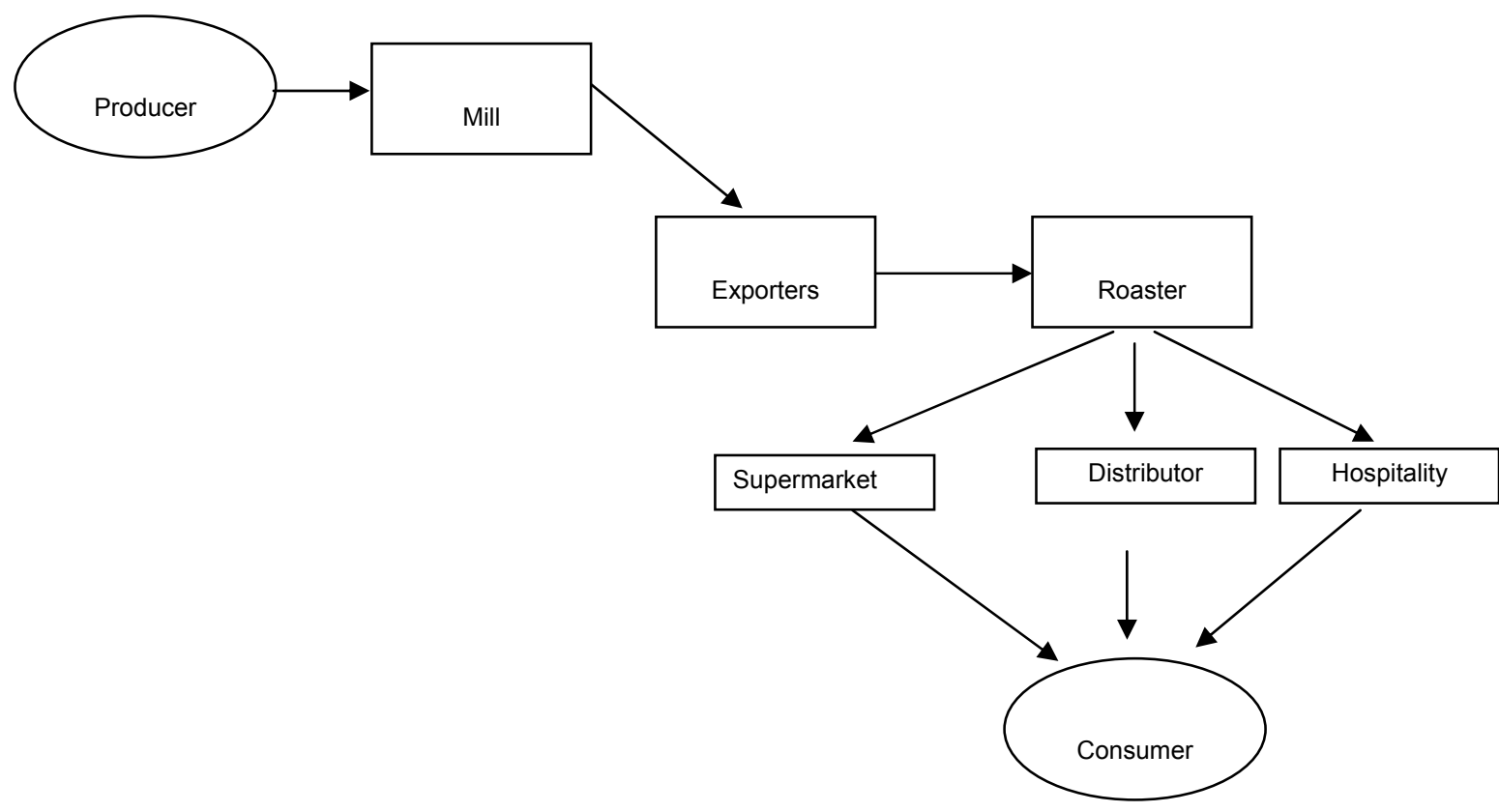




\section{Exhibit 4}

\section{Imports of Sustainable Coffee, North America and Europe} (thousands of bags $60 \mathrm{~kg}$ )
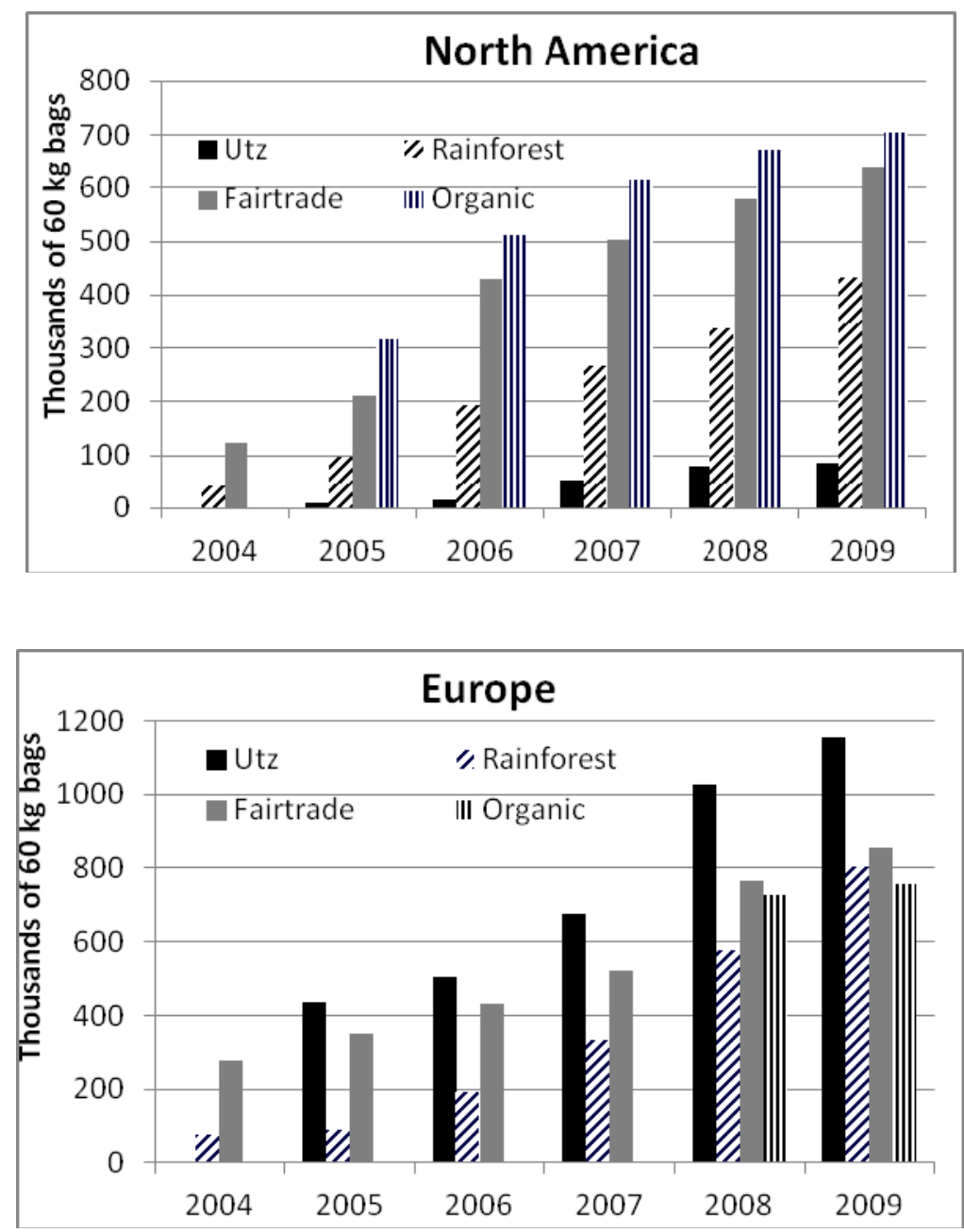

Source: International Trade Centre (ITC).Trends in the Trade of Certified Coffees. Geneva: ITC, 2011

\section{Exhibit 5}

Phases of the production process of hybrid coffee plants

\begin{tabular}{|l|l|}
\hline Phase 0 & Development of the embryos in the laboratory \\
\hline Phase 1 & Climate control for embryos in the laboratory, until they become seedlings \\
\hline Phase 2 & Climate control for seedlings outside the laboratory, with $80 \%$ shade \\
\hline Phases 3,4 & Climate control for seedlings outside the laboratory, with $40 \%$ shade \\
\hline
\end{tabular}




\section{Exhibit 6}

Financial results of the hybrid plants project

\begin{tabular}{|c|c|c|}
\hline Year & Investments (US\$) & $\begin{array}{c}\text { Operating Losses } \\
\text { (US\$) }\end{array}$ \\
\hline 2004 & 310,000 & 251,000 \\
\hline 2005 & 139,000 & 296,000 \\
\hline 2006 & 233,000 & 500,000 \\
\hline 2007 & 140,000 & 464,000 \\
\hline 2008 & 37,000 & 127,000 \\
\hline 2009 & 96,000 & 202,000 \\
\hline
\end{tabular}

Exhibit 7

Investments in Hybrid Plants, by growth phase (US \$)

\begin{tabular}{|r|c|c|c|c|c|c|c|}
\hline & Useful life & $\mathbf{2 0 0 4}$ & $\mathbf{2 0 0 5}$ & $\mathbf{2 0 0 6}$ & $\mathbf{2 0 0 7}$ & $\mathbf{2 0 0 8}$ & $\mathbf{2 0 0 9}$ \\
\hline Total investment & & $\mathbf{3 1 0 , 0 7 8}$ & $\mathbf{1 3 9 , 3 6 9}$ & $\mathbf{4 6 6 , 0 0 0}$ & $\mathbf{2 7 9 , 6 0 0}$ & $\mathbf{3 7 , 1 7 0}$ & $\mathbf{9 6 , 0 0 0}$ \\
\hline Phase 0 Infrastructure & 10 & 86,133 & 0 & 0 & 0 & 0 & 0 \\
\hline Laboratory equipment & 10 & 183,750 & 139,369 & 0 & 0 & 0 & 24,000 \\
\hline Vehicles & 5 & 40,195 & 0 & 0 & 0 & 0 & 0 \\
\hline Phase 1 & & 0 & 0 & 35,000 & 21,000 & 37,170 & 24,000 \\
\hline Phase 2 & 10 & 0 & 0 & 35,000 & 21,000 & 37,170 & 24,000 \\
\hline Tables and tunnels & 10 & 0 & 0 & 77,500 & 46,500 & 0 & 24,000 \\
\hline Trays and tubes & 5 & 0 & 0 & 26,250 & 15,750 & 0 & 0 \\
\hline Thasles and tunnels & 10 & 0 & 0 & 68,000 & 40,800 & 0 & 24,000 \\
\hline & 5 & 0 & 0 & 26,250 & 15,750 & 0 & 0 \\
\hline
\end{tabular}




\section{Exhibit 8}

Variable costs for each hybrid coffee plant

\begin{tabular}{|c|c|}
\hline Phase & Variable cost per plant (US\$) \\
\hline 0 & 0.024 \\
\hline 1 & 0.026 \\
\hline 2 & 0.093 \\
\hline $3 \& 4$ & 0.003 \\
\hline
\end{tabular}

\section{Exhibit 9}

Total fixed costs by phase of production

\begin{tabular}{|c|c|c|}
\hline Phase & $\begin{array}{c}\text { Maximum production capacity } \\
\text { (number of plants) }\end{array}$ & $\begin{array}{c}\text { Total fixed costs } \\
\text { (US\$) }\end{array}$ \\
\hline 0 & $3,000,000$ & 100,071 \\
\hline 1 & $3,000,000$ & 30,113 \\
\hline 2 & 840,000 & 17,055 \\
\hline $3 \& 4$ & 540,000 & 17,055 \\
\hline
\end{tabular}

\section{Exhibit 10}

Sales Projections, Hybrid coffee plants

\begin{tabular}{|c|c|c|c|c|}
\hline Year & Phase 0 & Phase 1 & Phase 2 & Phases 3 \& 4 \\
\hline $\mathbf{2 0 1 0}$ & 150,000 & 560,000 & 240,000 & $1,050,000$ \\
\hline $\mathbf{2 0 1 1}$ & 0 & $1,250,000$ & 150,000 & $1,550,000$ \\
\hline $\mathbf{2 0 1 2}$ & 0 & $1,700,000$ & 0 & $1,550,000$ \\
\hline $\mathbf{2 0 1 3}$ & 0 & $1,950,000$ & 0 & $1,550,000$ \\
\hline $\mathbf{2 0 1 4}$ & 0 & $1,950,000$ & 0 & $1,550,000$ \\
\hline $\mathbf{2 0 1 5}$ & 0 & $1,950,000$ & 0 & $1,550,000$ \\
\hline $\mathbf{2 0 1 6}$ & 0 & $1,950,000$ & 0 & $1,550,000$ \\
\hline
\end{tabular}




\section{Exhibit 11}

Projected Returns from Conventional and Hybrid Coffee Plants (per hectare, in US\$)

\begin{tabular}{|c|c|c|c|c|c|c|}
\hline \multicolumn{7}{|c|}{ Renovation with conventional plants (Caturra) } \\
\hline Year & 1 & 2 & 3 & 4 & 5 & 6 \\
\hline Labor & 631 & 669 & 709 & 751 & 796 & 844 \\
\hline Cost of the plants & 1,450 & 145 & 0 & 0 & 0 & 0 \\
\hline Inputs & 800 & 848 & 899 & 953 & 1,010 & 1,071 \\
\hline Administrative costs & 240 & 254 & 270 & 286 & 303 & 321 \\
\hline Total Costs & 3,121 & 1,916 & 1,877 & 1,990 & 2,109 & 2,236 \\
\hline Yields & 0 & 0 & 25 & 30 & 35 & 35 \\
\hline Price per quintal (hundredweight) & 130 & 130 & 130 & 130 & 130 & 130 \\
\hline Total Income & 0 & 0 & 3,250 & 3,900 & 4,550 & 4,550 \\
\hline Net income & $-3,121$ & $-1,916$ & 1,373 & 1,910 & 2,441 & 2,314 \\
\hline Return on investment & \multicolumn{6}{|c|}{$28.1 \%$} \\
\hline Net present value & \multicolumn{6}{|c|}{2,494} \\
\hline \multicolumn{7}{|c|}{ Renovation with hybrid plants } \\
\hline Year & 1 & 2 & 3 & 4 & 5 & 6 \\
\hline Labor & 631 & 669 & 709 & 751 & 796 & 844 \\
\hline Cost of the plants & 2,320 & 232 & 0 & 0 & 0 & 0 \\
\hline Inputs & 800 & 848 & 899 & 953 & 1,010 & 1,071 \\
\hline Administrative costs & 240 & 254 & 270 & 286 & 303 & 321 \\
\hline Total Costs & 3,991 & 2,003 & 1,877 & 1,990 & 2,109 & 2,236 \\
\hline Yields & 0 & 20 & 35 & 42 & 49 & 49 \\
\hline Price per quintal (hundredweight) & 130 & 130 & 130 & 130 & 130 & 130 \\
\hline Total Income & 0 & 2,600 & 4,550 & 5,460 & 6,370 & 6,370 \\
\hline Net income & $-3,991$ & 597 & 2,673 & 3,470 & 4,261 & 4,134 \\
\hline Return on investment & \multicolumn{6}{|c|}{$58.1 \%$} \\
\hline Net present value & \multicolumn{6}{|c|}{9,323} \\
\hline
\end{tabular}

